\title{
EDITORIAL
}

\section{Sehat Diusia Senja}

Pembaca yang terhormat, judul diatas saya angkat setelah membaca salah satu artikel yang ada pada pada edisi kali ini yaitu faktor-faktor yang berhubungan dengan hipertensi pada lansia di atas umur 65 tahun. Menjadi lanjut usia (lansia) merupakan suatu proses yang alamiah dan tidak dapat dihindari. Ketika saat itu datang tentunya kita berharap menjadi lansia yang sehat, mandiri dan kuat serta masih dapat membantu keluarga dan masyarakat apabila diperlukan. Salah satu negara yang mempunyai Umur Harapan Hidup yang tertinggi di dunia adalah Jepang. Untuk kaum hawa, harapan hidup mencapai 86,4 tahun, sedangkan pria sedikit lebih rendah, yakni 79,6 tahun. Umur Harapan Hidup (AHH) merupakan salah satu indikator atau penilaian derajat kesehatan suatu negara dan digunakan sebagai acuan dalam perencanaan program-program kesehatan. Angka Harapan Hidup disebut juga lama hidup manusia di dunia. Di Indonesia, berdasarkan Laporan CIA World Factbook Tahun 2011 yang dipublikasikan Wikipedia, UHH di Indonesia berada pada peringkat 108 dari 191 Negara di dunia; Secara keseluruhan UHH di Indonesia adalah 70,76 tahun, laki-laki 68,26 tahun dan Perempuan 73,38 tahun.

Keberhasilan pembangunan kesehatan telah memperpanjang usia lama hidup di Indonesia. Diharapkan pada tahun 2014, UHH di Indonesia adalah 72 tahun. Dengan meningkatnya usia harapan hidup maka akan terjadi perubahan struktur penduduk dengan bertambahnya penduduk lanjut usia. Hasil Sensus Penduduk tahun 2010, Indonesia termasuk lima besar negara dengan jumlah penduduk lanjut usia terbanyak di dunia yakni, mencapai 18,1 juta jiwa atau 7,6 persen dari jumlah penduduk. Jumlah penduduk lansia 60 tahun atau lebih diperkirakan akan terus meningkat sehingga pada tahun 2025 diperkirakan mencapai jumlah 36 juta jiwa.

Bertambahnya penduduk lansia, perlu mendapatkan perhatian yang serius, agar lansia dapat berdaya guna baik untuk dirinya sendiri maupun orang lain. Pada lansia, terjadi kemunduran sel-sel karena proses penuaan yang berakibat pada kelemahan otot, sehingga mudah sekali terjangkit penyakit-penyakit degeneratif seperti hipertensi, osteoporosis, diabetes melitus, jantung koroner, stroke dan lain sebagainya. Penyakit degeneratif tersebut memerlukan pengobatan yang lama dengan biaya yang tidak sedikit. Hal ini tentunya akan berdampak pada perekonomian penderita maupun keluarganya. Penyakit degeneratif salah satu penyebabnya adalah pola hidup yang tidak sehat. Untuk itu maka upaya yang dilakukan diprioritaskan pada upaya pencegahan (preventif) dan promotif, dengan terus mensosialisasikan pola hidup sehat sedini mungkin. Pola hidup sehat adalah perilaku hidup sehat dengan mengkonsumsi makanan yang seimbang, olahraga dengan teratur, istirahat yang cukup, tidak merokok, tidak mengkonsumsi minuman keras, memeriksakan kesehatan dengan teratur, dan meningkatkan keimanan dan ketaqwaan terhadap Tuhan Yang Maha Esa.

Untuk mencapai kesehatan lansia, penerapan pola hidup sehat sudah dimulai sedini mungkin, mulai dari dalam kandungan, bayi, balita, anak sekolah, remaja, dewasa sampai memasuki usia lansia. Setiap fase kehidupan tersebut mempunyai pendekatan kesehatan yang berbeda-beda untuk mencapai derajat kesehatan yang optimal. Perlu kerjasama dalam berbagai pihak seperti pemerintah, lembaga atau institusi kesehatan, sekolah dan perguruan tinggi, tokoh masyarakat dan masyarakat serta diri sendiri untuk melakukan upaya-upaya kesehatan yaitu preventif dan promotif ketika sehat, kuratif dengan memberikan pelayanan kesehatan yang optimal serta rehabilitatif apabila mengalami masalah kesehatan yang perlu dipulihkan.

Kembali ke artikel yang ditulis oleh Sri Agustina, Siska Mayang Sari dan Reni Savita, disimpulkan bahwa pada umumnya lansia diatas usia 65tahun yang mengalami hipertensi adalah mereka yang berasal dari suku Melayu, berjenis kelamin lakilaki, mempunyai riwayat hipertensi, mempunyai kebiasaan merokok, mengalami stress dan tidak rutin berolah raga. Hal-hal tersebut menegaskan bahwa pola hidup yang tidak sehat beresiko terhadap kejadian hipertensi. Oleh karena itu, menjadi lansia yang tetap sehat, tetap optimis, dan bahagia di hari tua, maka berusaha selalu hidup sehat dan lebih mendekatkan diri kepada yang Maha Kuasa. Beberapa hal yang perlu diperhatikan agar tetap sehat diusia lanjut antara lain adalah faktor gizi (makanan dan pola makan), olahraga dan gaya hidup. Para lansia dapat mengatur pola makan dengan mengonsumsi makanan yang tidak berlebihan, tetapi cukup mengandung zat-zat gizi yang diperlukan, membatasi konsumsi lemak, gula dan garam, cukup mengkonsumsi makanan yang berserat (buah-buahan dan sayuran). menghindari rokok dan minuman alkohol. Selain faktor gizi, rutinitas dalam berolohraga perlu dilakukan, dengan olahraga yang 
tidak terlalu berat seperti berjalan kaki. Dengan berjalan kaki dapat melatih kekuatan otot jantung, kaki dan menjaga kelancaran pernafasan bagi lansia.

Sekali lagi, upaya preventif dan promotif perlu dilakukan ketika kita sehat dengan menerapkan pola hidup yang sehat agar kelak ketika lansia menjadi lansia yang sehat, ceria, mandiri terhindar dari penyakit, bisa berdaya guna baik untuk diri sendiri, keluarga maupun masyarakat. 